\title{
Fruit Size, Yield, \\ and Market Value of 'GoldRush' \\ Apple are \\ Affected by \\ Amount, Timing and Method of Nitrogen Fertilization
}

\author{
James M. Wargo, ${ }^{1}$ \\ Ian A. Merwin, ${ }^{2}$ and \\ Christopher B. Watkins ${ }^{2}$
}

Additional IndeX words. Malus $\times$ domestica, tree-fruit nutrition, tree physiology, orchard economics

Summary. 'GoldRush' is a new scab (Venturia inaequalis) resistant apple (Malus $\times$ domestica) with excellent flavor and storage qualities that tends to produce small and russeted fruit. We investigated the effects of rate, timing, and method of nitrogen $(\mathrm{N})$ fertilizers on 'GoldRush' fruit size and quality during 1998-99. Fertilizer treatments were 1 ) no $\mathrm{N}$ fertilizer (control); 2) a low $\mathrm{N}$ rate of $45 \mathrm{kgha}^{-1}$ (40.1 lb/acre) applied in April (LNApr); 3) a low $\mathrm{N}$ rate of $45 \mathrm{~kg} \cdot \mathrm{ha}^{-1}$ applied half in April and half in June (LN-Apr+Jun); 4) a high $\mathrm{N}$ rate of 90 $\mathrm{kg} \mathrm{ha}^{-1}(80.3 \mathrm{lb} /$ acre $)$ split in April and June (HN-Apr+Jun); 5) a high $\mathrm{N}$ rate of $90 \mathrm{~kg} \cdot \mathrm{ha}^{-1}$ applied in April, May, June, and July at $22.5 \mathrm{~kg} \cdot \mathrm{ha}^{-1}$ (20 lb/acre) each month (HNApr+May+Jun+Jul); and 6) canopy sprays of $1 \%(w t / w t)$ urea-N, equivalent to $7 \mathrm{~kg} \cdot \mathrm{ha}^{-1}(6.2 \mathrm{lb} / \mathrm{acre})$ applied monthly in May, June, July, and August (foliar urea). In 1998, an additional foliar urea spray at $\mathbf{5 \%}(\mathrm{wt} /$ wt) concentration was applied to trees after harvest. The first year's $\mathrm{N}$

This report is based upon the MS research of the firs author, supported in part by grants from the New York Apple Research and Development Program, and CSREES Hatch Project NYC-142409. The author thank Marvin Pritts and Lailiang Cheng for critical reviews of this manuscript.

${ }^{1}$ Fruit Extension Associate, Cornell Cooperative Ex tension, 4487 Lake Ave, Lockport, NY 14094.

${ }^{2}$ Associate Professor of Horticulture, Dept. of Horticulture, Cornell Univ., Ithaca, NY 14853. 
treatments did not affect relative average fruit weights or total yields, but unfertilized trees produced more fruit in smaller size categories. Nitrogen fertilization resulted in greener and softer fruit both years. In the second year, all $\mathrm{N}$ additions increased yields compared with controls, but average fruit weight was inversely correlated with crop load. Foliar urea sprays and $\mathrm{HN}$ -

Apr+May+Jun+Jul treatments increased yields the most. Fruit from LN-fertilized trees were normally distributed across a range of eight box-count size categories, peaking at size 100 both years. In the unfertilized control, fruit size was skewed into smaller size categories and yield was reduced. Total yields were greatest in foliar urea and $\mathrm{HN}$ Apr+May+Jun+Jul treatments, but fruit-size distribution was skewed into smaller categories, peaking at size 138 in the second year. Foliar urea and HN-Apr+May+Jun+Jul treatments produced the highest crop value, but when estimated labor and fertilizer costs were considered, foliar urea and LN-Apr+Jun were the most efficient treatments. Nitrogen fertilizer improved fruit size and market value, but average fruit size in all treatments remained relatively small in both years, indicating that $\mathrm{N}$ fertilization alone may not increase fruit size in 'GoldRush.'

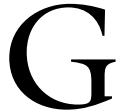
oldRush' is a scab-resistant apple variety released in 1994 from Purdue University in West Lafayette, Ind. 'GoldRush' has high sugar and acid content, and excellent storage qualities. Its flavor, acidity, and texture are retained for more than 6 months in regular cold storage and its appearance and eating quality actually improve after several months in storage (Crosby et al., 1994). These traits could make 'GoldRush' an ideal variety for organic growers and fruit processors or directmarketers without controlled atmosphere storage facilities. However, production of 'GoldRush' has been limited by its tendency to produce small fruit even with chemical thinning and irrigation. Apple growers receive premium prices for larger fruit, and processors set minimum size requirements for most varieties. Therefore, inadequate fruit size could impede acceptance of 'GoldRush' by growers and processors.

Fruit size in apple is determined by the interaction of varietal genetic traits, environmental conditions and cultural practices in the orchard. Nitrogen fertilization is a common practice to increase fruit size and yield, and maintain adequate tree vigor (Stiles and Reid, 1991). However, the effects of $\mathrm{N}$ fertilization are variable, and some studies have shown little or no fruit-size response to increasing rates of $\mathrm{N}$ fertilization (Goode and Higgs, 1977; Hipps et al., 1990; Johnson and Samuelson, 1990; Neilsen et al., 1999). Furthermore, fruit size and yield increases in response to $\mathrm{N}$ fertilizers are sometimes offset by undesirable impacts on fruit color and quality (Fallahi et al., 1997; Raese and Drake, 1997). If tree $\mathrm{N}$ reserves are already adequate, then fertilizer applications may be counter-productive (Magness et al., 1948). When tree $\mathrm{N}$ demand exceeds soil $\mathrm{N}$ availability, trees will usually respond in growth and yield to applied $\mathrm{N}$ fertilizer. However, when soil $\mathrm{N}$ availability exceeds tree $\mathrm{N}$ demand, trees are often unresponsive to applied $\mathrm{N}$, crop uptake of $\mathrm{N}$ fertilizer decreases, and the $\mathrm{N}$ leaching potential increases (Weinbaum, et al., 1992).

There are no previous published studies of 'GoldRush' fruit-size responses to $\mathrm{N}$ fertilizers, and sufficiency ranges for leaf $\mathrm{N}$ of 'GoldRush' in New York have been estimated at $2.2 \%$ to $2.4 \%$ without conclusive data (Stiles and Reid, 1991). This study was conducted to determine if $\mathrm{N}$ fertilizer treatments would increase fruit size of 'GoldRush,' and to evaluate different rates (amounts), times and methods of $\mathrm{N}$ fertilization for this apple variety.

\section{Methods and materials}

Two adjacent blocks of 'GoldRush' trees planted in 1994 (82 trees) and 1996 (98 trees) in a research orchard in Lansing, N.Y. were selected for this experiment. All trees were on 'Malling $7 \mathrm{a}$ ' (M.7a) rootstock, spaced $2.4 \times 4.8$ $\mathrm{m}(8 \times 16 \mathrm{ft})$ apart and trained to a modified vertical axe system on metal poles. The orchard soil was a silty clay loam (mixed, mesic, Glosaquic Hapludalf) with an average $\mathrm{pH}$ of 6.6, and $4.0 \%$ organic matter. Weeds were suppressed in a 1.2 -m-wide (4-ft) strip in tree rows with post-emergent herbicide applications in May and July each year, and alleyways were maintained in mowed sod groundcover. Trees were trickle irrigated whenever average soil water potential dropped below $-85 \mathrm{kPa}$ (centibars) in the tree row, with pressure compensating drip emitters at 40.6- $\mathrm{cm}$ (16-inch) intervals adjacent to each tree. Leaf $\mathrm{N}$ content of trees averaged $2.6 \%$ the year before the study (1997), and all trees were fertilized with 561.2 $\mathrm{kg} \mathrm{ha}^{-1}(500 \mathrm{lb} / \mathrm{acre})$ of sulfate of potash-magnesium in November each year. Pruning, chemical fruit thinning and other cultural practices were typical for commercial apple orchards in the northeastern U.S.

EXPERIMENTAL DESIGN AND TREATMENTS. The experimental design was a randomized complete block with six treatments. In both 1998 and 1999, the $\mathrm{N}$ fertilizer treatments were 1 ) no $\mathrm{N}$ fertilizer (control); 2 ) a low $\mathrm{N}$ rate of 45 $\mathrm{kg} \mathrm{ha}^{-1}$ applied in April (LN-Apr); 3 ) a

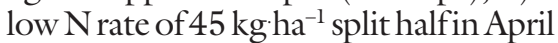
and half in June (LN-Apr+Jun); 4) a high $\mathrm{N}$ rate of $90 \mathrm{~kg}^{-1} \mathrm{~h}^{-1}$ split in April and June (HN-Apr+Jun); 5 ) a high $\mathrm{N}$

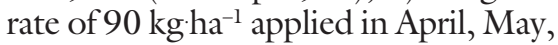
June, and July at $22.5 \mathrm{~kg} \cdot \mathrm{ha}^{-1}$ each month (HN-Apr+May+Jun+Jul); and 6) canopy sprays of $1 \%$ (wt/wt) urea-N, equivalent to equivalent to $8 \mathrm{~g}(0.2 \mathrm{oz})$ per tree or $7 \mathrm{kgha}^{-1}$ applied as four treatments in May, June, July, and August each year (foliar urea). In 1998, a fifth urea spray was applied at 5\% (wt/ wt) concentration in the foliar $\mathrm{N}$ treatment, equivalent to $40 \mathrm{~g}(1.4 \mathrm{oz})$ per

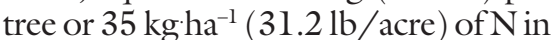
early November after harvest when leaves were still green and functional. Urea sprays were applied to the point of leaf runoff, so that larger trees (those planted in 1994 ) received about $50 \%$ more urea per tree than the smaller trees (those planted in 1996).

Fertilizer $\mathrm{N}$ was applied to soil in the middle of each designated treatment month both years, as granular ammonium nitrate $(36 \% \mathrm{~N})$, spread uniformly over the herbicide strip around each tree within the wetting pattern of irrigation emitters. Urea sprays were applied with a motorized airblast backpack sprayer in enough spray volume to wet each tree to incipient drip. Trees for experimental treatments were selected in May 1998, based upon uniform bloom density and tree vigor. For statistical analyses, trees were blocked by year of planting, and fertilizer treatments were replicated three times in each block for a total of six replicates. Treatments were applied to three-tree plots, with a single tree (usually the center one) selected for subsequent collection of data.

Leaf, SPUR AND SOIL SAMPLING. In 1998 and 1999, leaf samples were collected 60 to $70 \mathrm{~d}$ after petal fall for 
determination of foliar nutrient concentrations. Twenty-five leaves on each measurement tree were collected from the mid portion of current season shoots, composited, and dried to constant weight in paper bags at $80{ }^{\circ} \mathrm{C}(176.0$ $\left.{ }^{\circ} \mathrm{F}\right)$. Nitrogen concentrations were determined by a micro-Kjeldahl procedure (Greweling, 1976). Other macroand micro-nutrients were extracted from dry ashed samples in ammonium acetate, and concentrations were determined by inductively coupled plasma atomic emission spectroscopy (model 975 Plasma Atom Comp; Thermo JarrelAsh Corp, Franklin Mass.). Soil samples were collected at the same time as leaf sampling in July 1998. Soil cores were augured to a depth of $30 \mathrm{~cm}$ (11.8 inches) from three locations beneath each measurement tree and composited for analysis. Soil organic matter content was determined by loss on ignition at $500{ }^{\circ} \mathrm{C}\left(932.0^{\circ} \mathrm{F}\right)$ for $2 \mathrm{~h}$. Soil $\mathrm{pH}$ was measured in a 1 part soil : 1 part water solution. Soil macronutrient concentrations were determined by extraction in Morgan's solution at a 1 soil : 5 solution ratio and by atomic absorption flame spectrometry (Greweling and Peech, 1965). In March 1999, 10 spurs about $2.5 \mathrm{~cm}$ ( 1 inch) in length with flower buds attached were collected from the perimeter of each tree. The samples were composited and oven dried to constant weight in paper bags at $80^{\circ} \mathrm{C}$ $\left(176.0^{\circ} \mathrm{F}\right)$, and then analyzed for $\mathrm{N}$ using a micro-Kjeldahl procedure.

In 1999, bloom density and fruit set were assessed by selecting two branches about $2.5 \mathrm{~cm}$ in diameter on each tree, measuring basal limb circumference and counting blossom clusters during full bloom. Trees in all treatments were chemically thinned each year with napthaleneacetic acid and carbaryl at typical recommended rates and timing for New York orchards (Agnello et al., 1999), applied by airblast sprayer several weeks after petal fall. In late June when fruit drop was finished, the percentage of flowers that set was estimated on the same limbs by counting the remaining fruit. After terminal bud set in early August each year, 20 randomly selected terminal extension shoots from each tree were measured to assess tree growth.

Fruit sampling and eValuation. Fruit were harvested on 23 Oct. 1998 and 28 Oct. 1999. All fruit on each tree were counted and weighed, and average fruit weight was determined. A ten-fruit subsample was assessed for maturity, selecting fruit within $\pm 5 \%$ of the mean fruit weight for each replicate tree. Blush and background color were assessed with a chromameter (CR-200; Minolta Corp, Ransey, N.J.) by taking one separate reading from the blush and backside of each fruit, calibrated to illuminant level C. Chromaticity values were recorded in the Commission Internationale d'Eclairage (C.I.E.) L*, $a^{*}$, and $b^{*}$ color-space coordinates. These values were later converted to hue angle (McGuire, 1992). Percent blushed surface area of each apple was estimated visually. Firmness was measured on opposite sides of each fruit using an EPT-1 pressure tester (Lake City Technical Products, Lake City, Canada $)$ fitted with an $11.1-\mathrm{mm}(0.43-$ inch) Effigi tip. The juice resulting from these punctures was combined and assessed for soluble solids concentration with a digital refractometer (Atago PR100; McCormick Fruit Tech, Yakima, Wash.). Titratable acidity was measured on juice extracted from a blended composite of wedges taken from opposite sides of each apple, with an autotitrator (DL12; Mettler, Highstown N.J.). Fruit-maturity starch patterns were assessed using the Cornell generic starchiodine index chart, where 1 = immature and $8=$ overmature (Blanpied and Silsby, 1992). The remaining fruit were all then stored at $0^{\circ} \mathrm{C}\left(32.0^{\circ} \mathrm{F}\right)$ for subsequent evaluations.

Fruit SIZE DISTRIBUTION. Fruit from each replicate tree were separated into eight size categories with a Pomone Sizer (serial no. 99017), twolane grader, with six outlets (MAF Industries Inc., Traver, Calif.). Fruit were graded into box-count sizes [64, $72,80,88,100,113,125$, and 138 apples per 1-bushel (35.2-L) box, and culls] according to the weight of each fruit. The fruit-weight ranges defining each box-count size category were size $64=>332 \mathrm{~g}(11.7 \mathrm{oz})$, size $72=282$ to $332 \mathrm{~g}$ ( 10.0 to $11.7 \mathrm{oz})$, size $80=$ 252 to $282 \mathrm{~g}$ ( 8.9 to $10.0 \mathrm{oz})$, size 88 $=227$ to $252 \mathrm{~g}(8.0$ to $8.9 \mathrm{oz})$, size 100 $=204$ to $227 \mathrm{~g}(7.2$ to $8.0 \mathrm{oz})$, size 113 $=180$ to $204 \mathrm{~g}(6.4$ to $7.2 \mathrm{oz})$, size 125 $=161$ to $180 \mathrm{~g}(5.7$ to $6.4 \mathrm{oz})$, size 138 $=145$ to $161 \mathrm{~g}(5.1$ to $5.7 \mathrm{oz})$, and culls $<144 \mathrm{~g}(5.1 \mathrm{oz})$. Fruit size distribution data were recorded as the percentage in each box-size category, transformed to arcsine values to stabilize variances before statistical analyses.
ECONOMIC ANALYSIS OF N TREATMENTS. Yields from each $\mathrm{N}$ treatment were evaluated to estimate market value. Return per hectare was calculated from yield and fruit size distribution for each treatment. Price per box was estimated based on published market values for Washington State Extra Fancy 'Golden Delicious' apples (The Packer, 2000), during January 2000_-a likely time when 'GoldRush' fruit would be marketed following cold storage. Monetary crop values represented net return per 1 ha (2.47 acres) without deducting costs of fertilizer or labor.

Fruit QUALITY AFTER STORAGE. In 1998, fruit were removed from storage after 5 months and evaluated after 1 week at room temperature $\left[20^{\circ} \mathrm{C}(68\right.$ ${ }^{\circ} \mathrm{F}$ )]. Fruit quality evaluations (based on 10-fruit samples) included firmness, soluble solids, background color and the presence of decay or internal disorders. Evaluations were made using the same methods described for harvest tests.

Statistical analysis. Data were subjected to analysis of variance using the Statview 5.0 statistical package (SAS Inc., Cary, N.C.). Data from trees planted in 1994 and 1996 were pooled, using tree age as a blocking factor. When treatment effects were statistically significant at $P<0.05$, pairwise contrasts were made between treatments of interest. Data for each year were analyzed separately, due to significant year $\times$ treatment interactions in the analysis of variance.

\section{Results and discussion}

Tree $\mathbf{N}$ status. All $\mathrm{N}$ fertilizer treatments increased leaf $\mathrm{N}$ concentrations compared with controls in 1998 and 1999 (Table 1). However, amount and time of $\mathrm{N}$ application made little difference, and soil applications did not increase leaf $\mathrm{N}$ more than foliar urea sprays. At the time of sampling in 1998 , only $67.5 \mathrm{~kg} \cdot \mathrm{ha}^{-1}(60.2 \mathrm{lb} /$ acre $)$ had been applied in $\mathrm{HN}$-Apr+May+Jun+Jul split treatment. This may partly explain why leaf $\mathrm{N}$ concentrations were lower when $\mathrm{HN}$ was split over 4 months instead of 2 months. In both years, leaf $\mathrm{N}$ concentrations across all treatments were below the recommended range of 2.2 to $2.4 \%$ for comparable apple varieties in N.Y. (Stiles and Reid, 1991). Leaf $\mathrm{N}$ concentrations were especially low following extended drought early in the 1999 growing season, despite supplemental trickle irrigation. This observation suggests that a substantial portion 
of $\mathrm{N}$ uptake occurs outside the dripirrigated root-zone in humid region orchards. Although leaf $\mathrm{N}$ was reduced in the drought year (1999), fertilized trees still maintained higher $\mathrm{N}$ levels than controls.

Nitrate- $\mathrm{N}$ in soil samples during July 1998 differed among treatments (data not shown). Control plots had no detectable soil nitrate at the time of sampling, while foliar urea plots averaged $1.2 \mathrm{mg} \cdot \mathrm{kg}^{-1}$ (ppm). Splitting LN applications increased mid summer soil nitrate concentrations compared with the single early application ( $\mathrm{LN}-\mathrm{Apr}=$ $2.9 \mathrm{mg} \cdot \mathrm{kg}^{-1}$ versus LN-Apr+Jun $=17.5$ $\left.\mathrm{mg} \cdot \mathrm{kg}^{-1}\right)$. Higher amounts of $\mathrm{N}$ fertilization also increased soil nitrate concentrations relative to control and LN treatments; but there were negligible differences between the $\mathrm{HN}$ treatments $\left(\mathrm{HN}-\mathrm{Apr}+\mathrm{Jun}=44.3 \mathrm{mg} \cdot \mathrm{kg}^{-1}\right.$ versus HNApr+May+Jun+Jul = $\left.37.6 \mathrm{mg} \cdot \mathrm{kg}^{-1}\right)$. Soil samples were taken before the final (July) $\mathrm{N}$ fertilizer application in the $\mathrm{HN}$ Apr+May+Jun+Jul treatment, when only $67.5 \mathrm{kgha}^{-1}$ of $\mathrm{N}$ had been applied. Splitting $\mathrm{N}$ applications may increase soil $\mathrm{N}$ availability over an extended period of time, increasing $\mathrm{N}$-use efficiency and reducing the potential for $\mathrm{N}$ leaching (Weinbaum et al., 1992).

Most $\mathrm{N}$ fertilizer treatments increased spur $\mathrm{N}$ concentration compared with unfertilized controls (Table 1). The HN treatments increased spur $\mathrm{N}$ levels more than LN treatments regardless of application timing. Foliar urea sprays increased spur $\mathrm{N}$ compared with conventional LN soil applications in April, but we could not determine if the increase from foliar urea was attributed to spring, summer or 1998 postharvest urea sprays. Foliar urea sprays and/or high rates of soil-applied $\mathrm{N}$ in late spring and early summer increased tree $\mathrm{N}$ reserves more than low rates of soil-applied $\mathrm{N}$ earlier in the season. Other studies have also shown that autumn soil $\mathrm{N}$ applications and urea sprays increased reserve $\mathrm{N}$ content in dormant flower buds of pome fruits (Khemira et al., 1998; Oland, 1960; Sanchez et al., 1992; Williams, 1965).

SHOOT GROWTH, BLOOM DENSITY, AND FRUIT SET. Shoot growth increased in both years with soil $\mathrm{N}$ applications, and with foliar urea sprays in 1999 (Table 1). However, HN applications did not increase shoot growth more than $\mathrm{LN}$ in either year. Time of $\mathrm{N}$ application did not influence shoot growth in the HN treatment, but splitting LN between April and June increased shoot growth compared with a single April application in 1999. Shoot growth was positively correlated with leaf $\mathrm{N}$ in $1998\left(r^{2}=0.69, P<0.001\right.$, for linear regression model), but not in $1999\left(r^{2}=0.16, P=0.102\right)$.

Nitrogen fertilizers did not enhance bloom density compared with the control treatment, but $\mathrm{HN}$ Apr+May+Jun+Jul trees had greater bloom density and fruit set than HNApr+Jun trees, and all $\mathrm{N}$ treatments increased fruit set relative to controls (Table 1). Fertilization timing appeared to be an important factor in fruit set, with increased set when HN applications had extended into July. Improved fruit set the subsequent spring after midsummer $\mathrm{N}$ applications was also reported by Williams (1965), who specu-

Table 1. Nitrogen (N) treatment effects on leaf and spur $\mathbf{N}$ concentration, shoot growth (1998-99), and flowering and fruit set of 'GoldRush' apple trees in 1999. Values are means of six replicate trees per treatment.

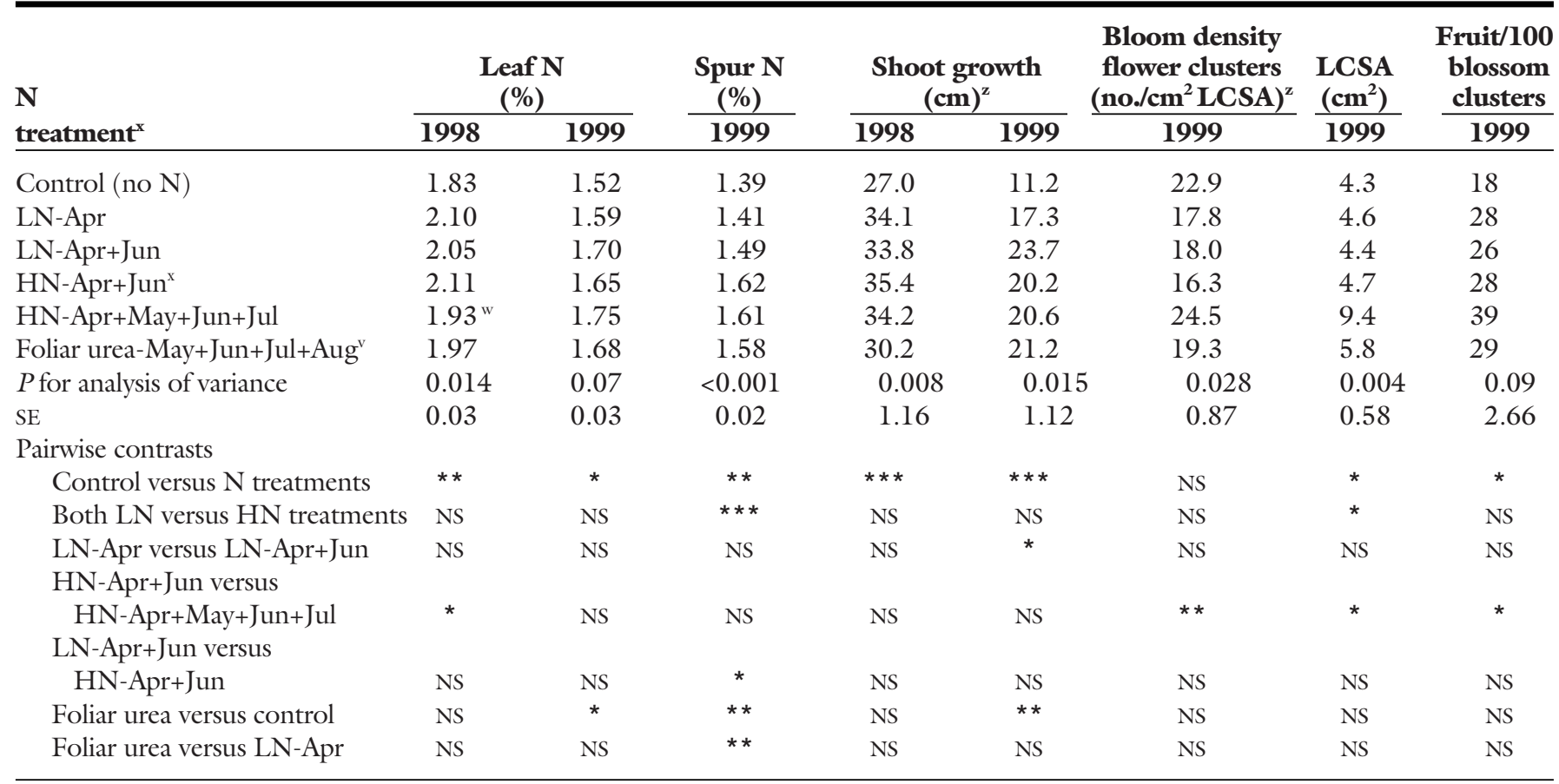

${ }^{\mathrm{z}} 1.0 \mathrm{~cm}=0.39$ inch

yLCSA $=$ limb cross-sectional area, $1.0 \mathrm{~cm}^{2}=0.16$ inch $^{2}$.

${ }^{\mathrm{x}} \mathrm{LN}=$ low $\mathrm{N}$ fertilizer rate $=45 \mathrm{~kg} \cdot \mathrm{ha}^{-1}(40.1 \mathrm{lb} /$ acre $)$ of soil-applied $\mathrm{N}$ fertilizer in April (Apr), or split equally in April and June (Apr + Jun) each year.

$\mathrm{HN}=$ high $\mathrm{N}$ fertilizer rate $=90 \mathrm{~kg} \cdot \mathrm{ha}^{-1}(80.3 \mathrm{lb} / \mathrm{acre})$ of soil-applied N fertilizer all in April, split equally in April and June, or in April, May, June, and July (Apr+May+Jun+Jul) each year.

wOnly $67.5 \mathrm{~kg} \cdot \mathrm{ha}^{-1}(60 \mathrm{lb} / \mathrm{acre})$ of this HN treatment had been applied at the time of leaf sampling in 1998.

${ }^{\mathrm{v}} 1 \%$ foliar urea sprays applied in May, June, July, and August (May+Jun+Jul+Aug) 1998 and 1999, and one $5 \%$ urea spray postharvest in 1998 . Trees planted in 1994 received 60 $\mathrm{kg} \cdot \mathrm{ha}^{-1}(53.5 \mathrm{lb} / \mathrm{acre})$ of urea-N in 1998, and $30 \mathrm{~kg} \cdot \mathrm{ha}^{-1}(26.8 \mathrm{lb} / \mathrm{acre})$ in 1999 . Trees planted in $1996 \mathrm{received} 35 \mathrm{~kg} \cdot \mathrm{ha} \mathrm{a}^{-1}(31.2 \mathrm{lb} / \mathrm{acre})$ of urea-N in 1998 , and $15 \mathrm{~kg} \cdot \mathrm{ha} \mathrm{a}^{-1}(13.4$ $\mathrm{lb} /$ acre) in 1999.

ss, $,{ }^{\star \star \star},{ }^{\star \star \star}$ Nonsignificant, or significant trends at $P<0.05,0.01$, or 0.001 respectively. 
lated that previous late summer $\mathrm{N}$ supply increased the effective pollination period during the next year's bloom. Unlike previous reports, foliar urea applications did not increase bloom density or fruit set in our trees (Khemira et al., 1998; Oland, 1960; Sanchez et al., 1992).

Fruit COLOR. Fully mature 'GoldRush' fruit have a yellow background color with lightly blushed reddish overtones, and all of our $\mathrm{N}$ treatments reduced the percentage of blushed surface in both years (Table 2). Red color intensity, measured as hue angle, was also lower on $\mathrm{N}$ fertilized trees in 1998. Differences in blush among N treatments were inconsistent from year to year, but HN tended to reduce blushed surface area and red color intensity relative to $\mathrm{LN}$.

Background color was greener on all $\mathrm{N}$ fertilized fruit, as evidenced by higher hue angles in both years (Table 2). In 1998, fruit from $H N$ treatments were greener compared with LN treatments, and fruit from trees receiving foliar urea were greener than fruit receiving LN-Apr fertilizer applications.
In 1999, yellow background color decreased in all $\mathrm{N}$ fertilized fruit relative to controls, but did not differ among methods, amounts or times of $\mathrm{N}$ application. Neilsen et al. (1984) found that high $\mathrm{N}$ supply delayed chlorophyll breakdown and reduced yellow background color in ripening 'Golden Delicious' apples, in agreement with our results from 1998. To the contrary, Hansen (1980) reported that soil $\mathrm{N}$ applications in late spring or early summer reduced yellow coloration relative to early spring $\mathrm{N}$ treatments, but we did not observe this trend.

Fruit Maturity and INTERnal QUALITY. Fruit maturity at harvest, as determined by starch index ratings, was not affected by $\mathrm{N}$ treatments either year (Table 2). Fruit firmness was reduced 2.0 to $5.5 \mathrm{~N}(0.4$ to $1.2 \mathrm{lb})$ by all $\mathrm{N}$ treatments relative to controls, but did not differ significantly among $\mathrm{N}$ rates and timing. Neilsen et al. (1984) also reported no difference in firmness of 'Golden Delicious' apple over a range of $\mathrm{N}$ fertilization from 30 to $180 \mathrm{~kg} \cdot \mathrm{ha}^{-1}$ (26.8 to $160.6 \mathrm{lb} /$ acre). Foliar urea did not reduce fruit firmness compared with unfertilized trees in 1998, but did in 1999. In a softer fleshed variety such a loss of firmness with $\mathrm{N}$ treatments could be detrimental, but 'GoldRush' fruit remained very firm even with the highest amounts of $\mathrm{N}$ fertilization in our study.

Soluble solids in fruit were above $14 \%$ in all treatments both years, and were higher in controls than fertilized trees in 1999 (Table 2). Fruit from the HN-Apr+May+Jun+Jul treatment had lower soluble solids compared to $\mathrm{HN}$ Apr+Jun, as did foliar urea compared to LN-Apr. Crop load also affected sugar concentrations in fruit, with lower soluble solids in fruit from more heavily cropped trees. Fertilizer N did not affect the titratable acidity of any fruit measured (data not shown).

After 5 months in refrigerated storage and 1 week at $20^{\circ} \mathrm{C}$, the differences in firmness or soluble solids that we had observed at harvest time in the various $\mathrm{N}$ treatments were no longer evident (data not shown). Overholser and Overley (1939) also reported that early and midsummer $\mathrm{N}$ fertilization reduced fruit firmness at harvest, but these dif-

Table 2. Nitrogen (N) fertilization effects on color and internal quality attributes of'GoldRush' apples at harvest in 1998 and 1999. Values are means of 10 fruit samples from six trees per treatment.

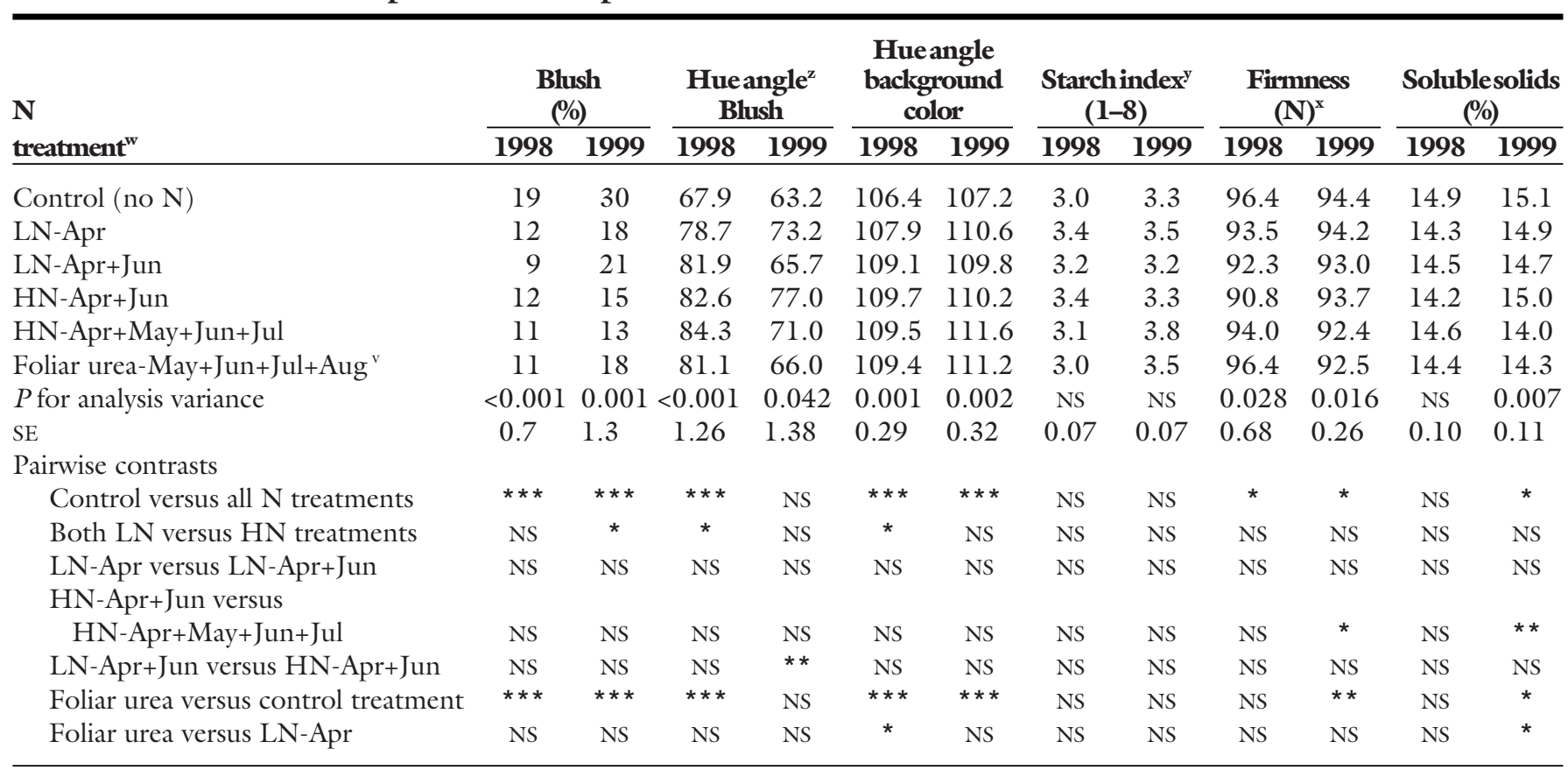

${ }^{\mathrm{z}}$ Hue angle values derived from a system where $0=$ red, $90=$ yellow, $180=$ green, and $270=$ blue.

yCornell starch chart: $1=$ no starch hydrolysis, $8=100 \%$ starch hydrolysis.

x $4.45 \mathrm{~N}=1.0 \mathrm{lb}$.

${ }^{\mathrm{w}} \mathrm{LN}=$ low $\mathrm{N}$ fertilizer rate $=45 \mathrm{~kg} \cdot \mathrm{ha}^{-1}(40.1 \mathrm{lb} /$ acre $)$ of soil-applied $\mathrm{N}$ fertilizer in April (Apr), or split equally in April and June (Apr+Jun) each year

$\mathrm{HN}=$ high $\mathrm{N}$ fertilizer rate $=90 \mathrm{~kg} \cdot \mathrm{ha}^{-1}(80.2 \mathrm{lb} / \mathrm{acre})$ of soil-applied N fertilizer all in April, split equally in April and June, or in April, May, June, and July (Apr+May+Jun+Jul) each year.

v $1 \%$ foliar urea sprays applied in May, June, July, and August (May+Jun+Jul+Aug) 1998 and 1999, and one 5\% urea spray postharvest in 1998 . Trees planted in 1994 received $60 \mathrm{~kg} \mathrm{ha}^{-1}(53.5 \mathrm{lb} / \mathrm{acre})$ of urea-N in 1998 , and $30 \mathrm{~kg} \mathrm{ha}^{-1}(26.8 \mathrm{lb} / \mathrm{acre})$ in 1999. Trees planted in $1996 \mathrm{received} 35 \mathrm{~kg} \mathrm{ha}{ }^{-1}(31.2 \mathrm{lb} / \mathrm{acre})$ of urea-N in 1998 , and $15 \mathrm{~kg}$ ha-l $(13.4 \mathrm{lb} /$ acre $)$ in 1999.

Ns, ${ }^{*, * *},{ }^{* * *}$ Nonsignificant, or significant trends at $P<0.05,0.01$, or 0.001 respectively. 
ferences diminished after 3 or 6 months in cold storage. 'GoldRush' flavor improves with cold storage and the variety is often stored for several months before marketing. Even after prolonged storage, background color remained greener for all fruit from $\mathrm{N}$ fertilized plots relative to the unfertilized control, but did not differ among $\mathrm{N}$ treatments (data not shown).

Fruit size and yield. Leaf $\mathrm{N}$ concentrations in our trees were relatively high the year before the first $\mathrm{N}$ treatments of this study, which may explain the lack of $\mathrm{N}$-fertilizer effects on fruit size, yield, crop load, or yield efficiency in 1998 (Table 3). In 1999, total yield and fruit number per tree were greater in all $\mathrm{N}$ treatments compared with controls. Amount of fertilization ( $\mathrm{HN}$ versus $\mathrm{LN}$ ) was not a significant factor, but timing and method of $\mathrm{N}$ application did affect yields. Higheryields were obtained with four split $\mathrm{HN}$ applications (Apr+May+Jun+Jul) instead of two (Apr+Jun); and foliar urea increased yield compared with soil applied LNApr treatments. In the $\mathrm{HN}$ Apr+May+Jun+Jul and foliar urea treat- ments, we attributed the greater yields to increased fruit set or decreased response to chemical thinning treatments. In a similar study with a small fruited apple variety, Neilsen et al. (1999) reported that yields were relatively insensitive to different rates and timing of soil $\mathrm{N}$ application, with no yield differences during 4 years of single $\mathrm{N}$ applications of $80 \mathrm{~kg} \cdot \mathrm{ha}^{-1}(7 \mathrm{l} .4 \mathrm{lb} /$ acre $)$ compared with split applications totaling 200 $\mathrm{kg} \mathrm{ha}^{-1}$ (178.4 lb/acre). Magness et al. (1948) also found that timing of $\mathrm{N}$ applications made little difference when tree $\mathrm{N}$ status was already adequate. Trees were relatively low in $\mathrm{N}$ status during both years of our study (Table 1), and responded similarly to $\mathrm{HN}$ and $\mathrm{LN}$ fertilizer applications in April and June. However, $\mathrm{HN}$ applications spread over a 4-month period elicited a greater yield response. This suggests that 'GoldRush' trees of low $\mathrm{N}$ status may be responsive to $\mathrm{N}$ application timings that increase $\mathrm{N}$ availability over an extended period. In our study, foliar urea sprays increased yield and crop load of 'GoldRush' more than the customary late spring soil $\mathrm{N}$ applications, even though relatively less
$\mathrm{N}$ was applied in the foliar treatments. In a comparable study, Fisher and Cook (1950) also found that spring foliar urea sprays increased fruit set and yield compared to similar amounts of $\mathrm{N}$ applied to soil beneath trees. These observations indicate that foliar urea sprays may increase yields more efficiently than soil $\mathrm{N}$ applications.

Yield efficiency (defined as harvested fruit per unit trunk cross-sectional area) was increased by $\mathrm{N}$ fertilization in 1999, and was greater with $\mathrm{HN}$ treatments compared with LN treatments (Table 3). Partitioning HN applications over 4 months (Apr+May+ Jun+Jul) improved yield efficiency relative to the same amount of $\mathrm{N}$ in two applications (Apr+Jun). Trees receiving foliar urea had higher yield efficiency compared with unfertilized controls, but not in comparison to trees receiving LN soil applications in April.

When crop load was included as a covariate in statistical analyses, mean fruit weight was not significantly affected by any treatment in either year, indicating that crop load itself was a major determinant of fruit size (Table

Table 3. Nitrogen (N) fertilization effects on yield characteristics of 'GoldRush' apple trees in 1998 and 1999. Values are means of six trees for each $\mathbf{N}$ fertilizer treatment.

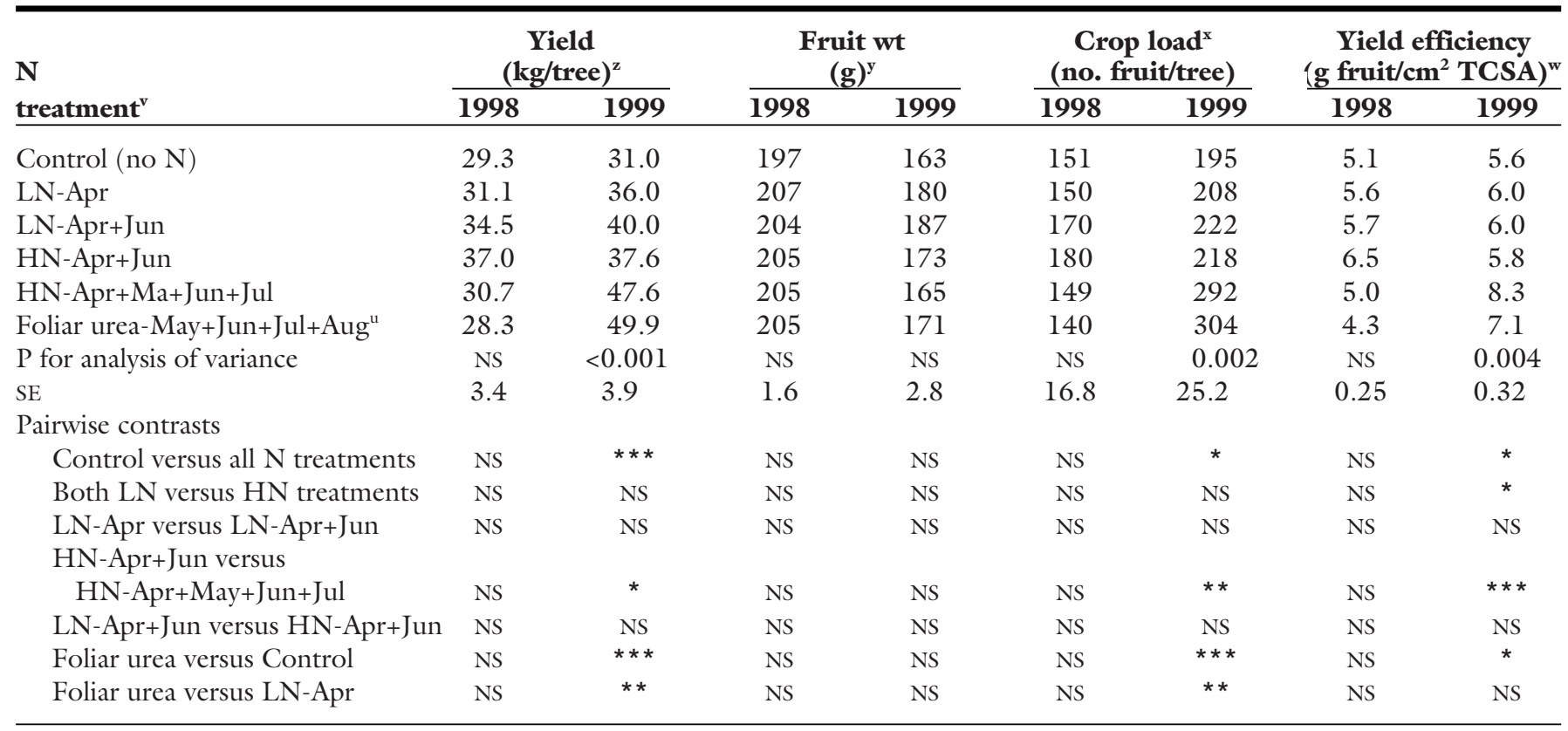

${ }^{\mathrm{z}} 1.0 \mathrm{~kg}=2.20 \mathrm{lb}$

y $28.35 \mathrm{~g}=1.0 \mathrm{oz}$.

${ }^{\mathrm{x}}$ Crop load was used as a covariate in analysis of variance.

wTCSA $=$ trunk cross-sectional area, $1 \mathrm{~cm}^{2}=0.16$ inch $^{2}$.

${ }^{v} \mathrm{LN}=$ low $\mathrm{N}$ fertilizer rate $=45 \mathrm{~kg}^{-1} \mathrm{ha}^{-1}(40.1 \mathrm{lb} /$ acre $)$ of soil-applied $\mathrm{N}$ fertilizer in April (Apr), or split equally in April and June (Apr+Jun) each year. HN = high $\mathrm{N}$ fertilizer rate $=90 \mathrm{kgha}^{-1}(80.2 \mathrm{lb} /$ acre $)$ of soil-applied N fertilizer all in April, split equally in April and June, or in April, May, June, and July (Apr+May+Jun+Jul) each year

"1\% foliar urea sprays applied in May, June, July and August (May+Jun+Jul+Aug) 1998 and 1999, and one 5\% urea spray postharvest in 1998. Trees planted in 1994 received 60 $\mathrm{kg} \cdot \mathrm{ha}^{-1}(53.5 \mathrm{lb} / \mathrm{acre})$ of urea- $\mathrm{N}$ in 1998 and $30 \mathrm{~kg} \cdot \mathrm{ha}^{-1}(26.8 \mathrm{lb} / \mathrm{acre})$ in 1999 . Trees planted in 1996 received $35 \mathrm{~kg} \cdot \mathrm{ha}^{-1}$ (31.2 lb/acre) of urea-N in 1998 , and $15 \mathrm{~kg} \cdot \mathrm{ha}^{-1}$ (13.4 lb/acre) in 1999 .

Ns,******* Nonsignificant, or significant trends at $P<0.05,0.01$, or 0.001 respectively. 
3). In other studies, $\mathrm{N}$ fertilizers have not increased fruit size when tree crop loads were also increased, although heavily fertilized trees usually produced the largest fruit (Beattie, 1958; Williams and Billingsley, 1974). In both years of our study, $\mathrm{N}$ fertilization tended to increase both total yield and fruit number per tree, but fruit size in $\mathrm{N}$-fertilized trees remained equivalent to that of

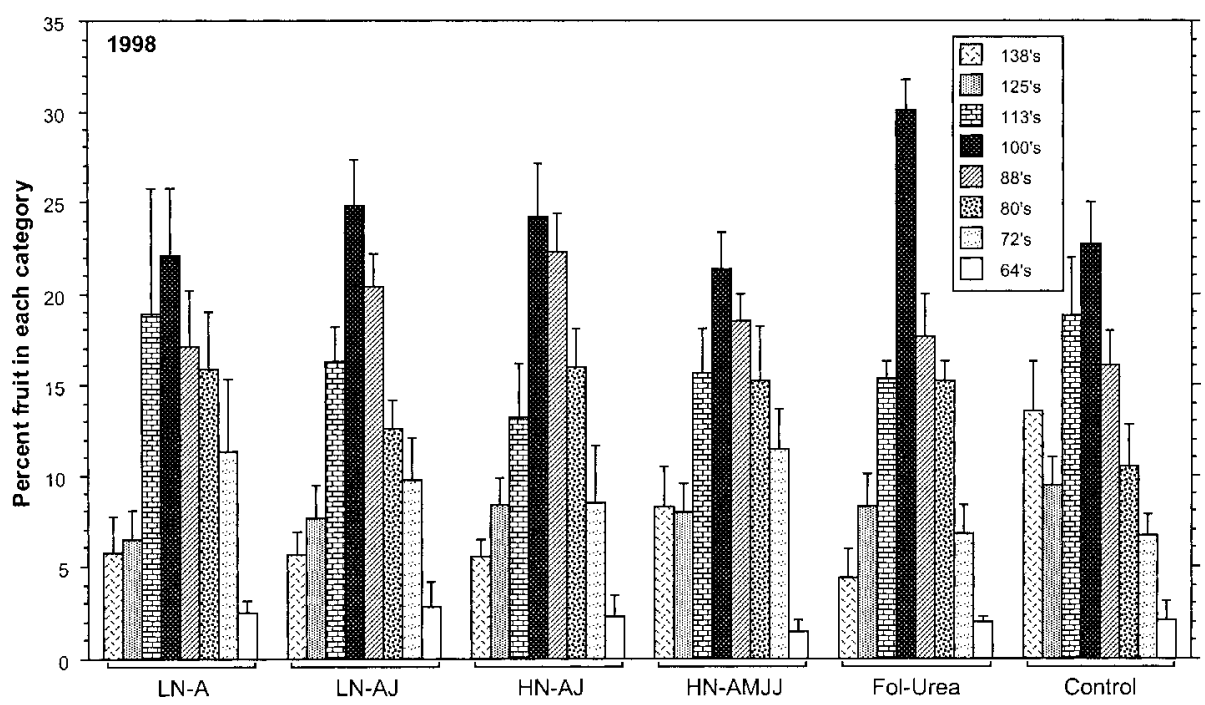

Fig. 1. Effect of nitrogen ( $N$ ) fertilizer treatments on bushel box-count fruit-size distribution of 'GoldRush' apples in 1998 ( 1 bushel = 35.2 L). Data were arcsine transformed before analysis. Histogram bars represent the means of all fruit harvested from six trees in each treatment, \pm sE. $L N=$ low $N$ rate, $H N=$ high $N$ rate, FolUrea = foliar urea, Control=no $\mathbf{N}$ applied, $A=A$ pril; $A J=A p r i l+J u n e$,

$\mathrm{AMJJ}=$ April+May+June+July. Fruitwere sorted according to box-size category as follows: Size $64 \geq 332 \mathrm{~g}$, size $72=282$ to $332 \mathrm{~g}$, size $80=252$ to $282 \mathrm{~g}$, size 88 = 227 to $252 \mathrm{~g}$, size $100=204$ to $227 \mathrm{~g}$, size113=180 to $204 \mathrm{~g}$, size $125=161$ to 180 $\mathrm{g}$, size $138=145$ to $161 \mathrm{~g}(28.4 \mathrm{~g}=1 \mathrm{oz})$. Treatment $\times$ box-size category interaction was nonsignificant $(P>0.05)$.

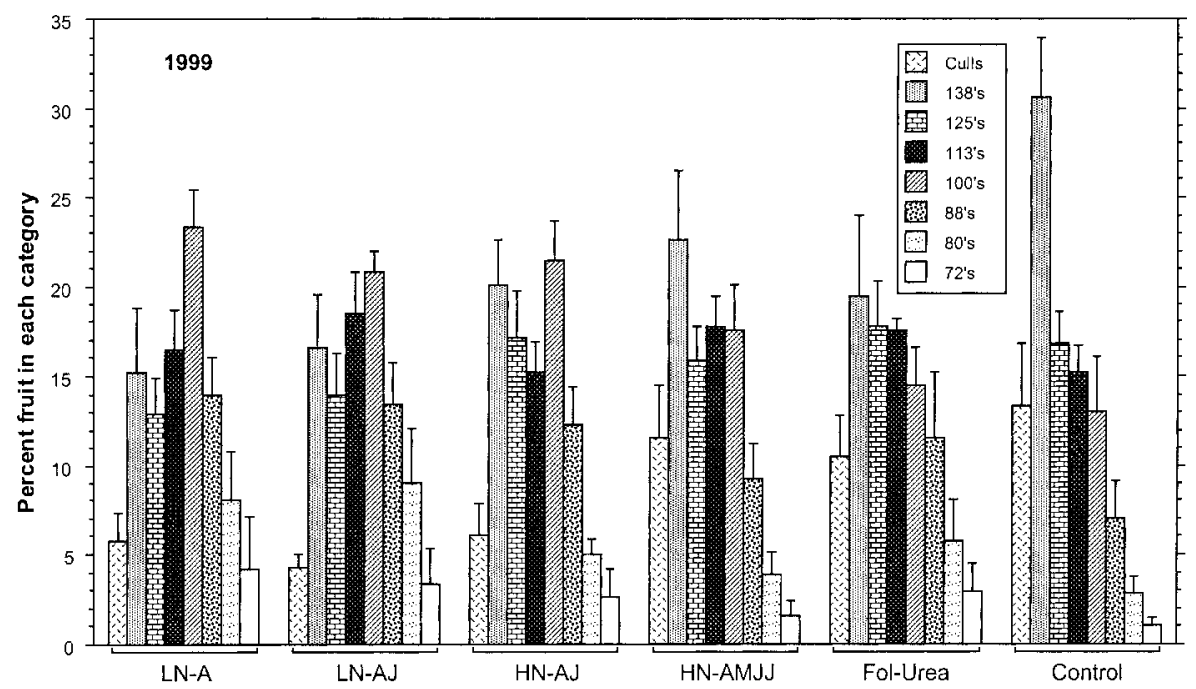

Fig. 2.Effect of nitrogen (N) fertilizer treatments on bushel box-count fruit-size distribution of 'GoldRush' apples in 1999 ( 1 bushel = 35.2 L). Data were arcsine transformed before analysis. Histogram bars represent the means of all fruit harvested from six trees in each treatment, \pm sE. $L N=$ low $N$ rate, $H N=$ high $N$ rate, FolUrea = foliar urea, Control=no $\mathbf{N}$ applied, $A=A$ pril; $A J=A p r i l+J u n e$, AMJJ=April+May+June+July. Fruit were sorted according to box-size category as follows: Size $64 \geq 332 \mathrm{~g}$, size $72=282$ to $332 \mathrm{~g}$, size $80=252$ to $282 \mathrm{~g}$, size 88 = 227 to $252 \mathrm{~g}$, size $100=204$ to $227 \mathrm{~g}$, size $113=180$ to $204 \mathrm{~g}$, size $125=161$ to 180 $\mathrm{g}$, size $138=145$ to $161 \mathrm{~g}(28.4 \mathrm{~g}=1 \mathrm{oz})$. Treatment $\times$ box-size category interaction was significant $(P<0.001)$. unfertilized trees with lower crop loads. Foliar urea sprays and $\mathrm{HN}$ Apr+May+Jun+Jul treatments increased yield per tree by 16 and $19 \mathrm{~kg}(35.3$ and $41.9 \mathrm{lb})$ respectively, with up to 100 more fruit per tree in these two treatments compared to others. We concluded that more aggressive chemical or hand thinning would be necessary to reap the potential benefits of increased fruit size in 'GoldRush' trees that receive soil or foliar $\mathrm{N}$ fertilization.

Fruit size distribution. Grading fruit by discrete box-count categories revealed substantially different trends than did comparisons of mean fruit weight, and enabled us to estimate some economic impacts of $\mathrm{N}$ treatments. In 1998, there were few differences in fruit-size categories among $\mathrm{N}$ treatments; all were distributed normally across box-count categories, peaking in the 100 fruit per box category (Fig. 1). Unfertilized controls tended to have more fruit in the smaller fruit size categories, and fewer in the larger size categories, but this trend was not statistically significant $(P>0.05)$. In 1999 , the interaction between $\mathrm{N}$ treatments and box-count categories was significant $(P<0.001)$ (Fig. 2), and there was a shift into smaller fruit size categories for all treatments, which we attributed to a very dry growing season and lower leaf $\mathrm{N}$ concentrations that year. Fruit from unfertilized control trees in 1999 graded mostly into smaller size categories (higher counts per box), peaking at size 138, with significantly fewer fruit in the 100 and 72-count categories relative to $\mathrm{N}$-fertilized trees. Regardless of $\mathrm{N}$ application timing, fruit from $\mathrm{LN}$ treatments were more normally distributed across fruit-size categories, peaking at size 100; they also had a smaller percentage of culls (fruit smaller than the 138-count size) compared to the control, HN-Apr+May+Jun+Jul, and foliar urea treatments. The size distribution of fruit from $\mathrm{HN}$ Apr+May+Jun+Jul and foliar urea treatments was skewed into the smaller size categories, peaking in the 138 fruit-perbox size in 1999. The HN-Apr+Jun treatment produced results intermediate between the other $\mathrm{N}$ treatments, with a fruit-size distribution skewed more into smaller fruit size categories, peaking in thel00-count box size.

Compared with unfertilized trees, $\mathrm{N}$ applications increased total yields and normalized the distribution of fruit size across the range of box-count 
Table 4. Estimated market value of 'GoldRush' apples in 1999. Monetary values based on cropyield per hectare and the relative proportions of total yield graded into each box-size category. Price per box was based on returns for Washington State grade Extra Fancy'Golden Delicious' apples (The Packer, 2000).

\begin{tabular}{|c|c|c|c|c|c|c|c|}
\hline \multirow{2}{*}{$\begin{array}{l}\mathbf{N} \\
\text { treatment }^{\mathrm{x}}\end{array}$} & \multicolumn{6}{|c|}{ Monetary value per box size category $(\$ / h a)^{y}$} & \multirow{2}{*}{$\begin{array}{c}\text { Total value } \\
(\$ / \mathbf{h a})\end{array}$} \\
\hline & Culls $^{x}$ & 138 size & 125 size & 113 size & 100 size & $88-72$ size & \\
\hline Control (no N) & 383 & 3,341 & 2,528 & 1,008 & 2,313 & 2,520 & 13,576 \\
\hline LN-Apr & 193 & 1,937 & 2256 & 1,272 & 4,818 & 7,057 & 19,405 \\
\hline LN-Apr+Jun & 151 & 2,293 & 2,609 & 1,560 & 4,851 & 8,065 & 21,824 \\
\hline HN-Apr+Jun & 208 & 2,629 & 3,099 & 1,296 & 4,497 & 5,629 & 19,264 \\
\hline $\mathrm{HN}-\mathrm{Apr}+\mathrm{May}+\mathrm{Jun}+\mathrm{Jul}$ & 507 & 3,795 & 3,642 & 1,812 & 4,786 & 5,209 & 22,417 \\
\hline Foliar urea-May+Jun+Jul+Aug & 484 & 3,420 & 4,295 & 1,872 & 4,144 & 7,561 & 24,530 \\
\hline
\end{tabular}

${ }^{\mathrm{z}} \mathrm{LN}=$ low $\mathrm{N}$ fertilizer rate $=45 \mathrm{~kg} \cdot \mathrm{ha}^{-1}(40.1 \mathrm{lb} /$ acre $)$ of soil-applied $\mathrm{N}$ fertilizer in April (Apr), or split equally in April and June (Apr+Jun) each year. HN = high $\mathrm{N}$ fertilizer rate $=90 \mathrm{~kg} \cdot \mathrm{ha}^{-1}(80.2 \mathrm{lb} / \mathrm{acre})$ of soil-applied $\mathrm{N}$ fertilizer all in April, split equally in April and June, or in April, May, June, and July (Apr+May+Jun+Jul) each year.

y Monetary value per packed 1 -bushel $(35.2 \mathrm{~L})$ box: Size $138=\$ 8.00$, size $125=\$ 11.00$, size $113=\$ 12.00$, size $100=\$ 13.00$, sizes 88 to $72=\$ 17.00$. The box value for size category 138 was estimated, because no price quote was available; $\$ 1 / \mathrm{ha}=\$ 0.40 /$ acre

${ }^{x}$ Monetary value for culls assessed at $\$ 0.11 / \mathrm{kg}(\$ 0.0445 /$ acre $)$ based on juice price for 'Golden Delicious' apples.

v $1 \%$ foliar urea sprays applied in May, June, July and August (May+Jun+Jul+Aug) of 1998 and 1999, and one 5\% urea spray postharvest in 1998. Trees planted in 1994 received $60 \mathrm{~kg} \cdot \mathrm{ha}^{-1}(53.5 \mathrm{lb} / \mathrm{acre})$ of urea-N in 1998, and $30 \mathrm{~kg}^{-1} \mathrm{ha}^{-1}(26.8 \mathrm{lb} / \mathrm{acre})$ in 1999 . Trees planted in $1996 \mathrm{received} 35 \mathrm{~kg} \cdot \mathrm{ha}^{-1}(31.2 \mathrm{lb} / \mathrm{acre})$ of urea-N in 1998 , and $15 \mathrm{~kg} \cdot \mathrm{ha} \mathrm{a}^{-1}$ (13.4 lb/ acre) in 1999 .

categories. Comparing fruit yields and size categories among different timing and amounts of $\mathrm{N}$ applications, the differences among $\mathrm{N}$ fertilizer programs were usually associated with crop load effects. Low $\mathrm{N}$ trees yielded 7.6 to $14 \mathrm{~kg}$ (16.8 to $30.9 \mathrm{lb}$ ) less per tree compared to HN-Apr+May+Jun+Jul and foliar urea treatments. This reduction in tree crop load in LN and control treatments apparently increased the percentage of fruit in larger size categories. In a comparable study, Beattie (1958) reported no differences in average fruit weight between high and low $\mathrm{N}$ treatments; only when fruit were sorted according to box-size counts were differences among treatments detected. Future studies of fruit sizing effects should take this into consideration when economic responses to fertilizer treatments are of interest.

ECONOMIC ANALYSIS OF N FERTILIZATION. Nitrogen treatments had a major impact on economic returns for 'GoldRush' in our study, based on fruit size responses (Table 4 ). The $\mathrm{N}$ treatments increased net returns by U.S. $\$ 5,688$ to $\$ 10,954$ per ha $(\$ 2,302$ to $\$ 4,433$ per acre) compared with unfertilized controls. This was attributed to a combination of increased yields and a greater percentage of fruit in larger box-count size categories. $\mathrm{HN}-\mathrm{Apr}+\mathrm{Jun}$ did not increase net returns compared to LN-Apr, or LNApr+Jun treatments; but $\mathrm{HN}$ Apr+May+Jun+Jul and foliar urea applications resulted in substantially higher crop market values compared with other $\mathrm{N}$ treatments, primarily due to greater total yields. Additionally, split applications of LN-Apr+Jun in- creased net returns more than a single LN-Apr application. The LN-Apr+Jun treatment produced fruit of similar market value compared to $\mathrm{HN}$ Apr+May+Jun+Jul, even though total yields were lower in the LN treatment. The higher percentage of LN fruit in larger fruit-size categories evidently compensated for greater yields of smaller fruit in HN treatments.

Fruit size was not the only factor that influenced economic returns for $\mathrm{N}$ treatments, as shown by a comparison of net returns in LN-Apr, HNApr+May+Jun+Jul, and foliar urea treatments. LN-Apr resulted in a higher percentage of fruit in larger size categories, but lower net returns due to reduced total yields. This trend illustrates the importance of considering both total yields and fruit-size distributions in evaluating fruit-tree responses to $\mathrm{N}$ fertilization. The costs of $\mathrm{N}$ fertilizers and labor were not factored into our market-value estimates, and would certainly have been reduced in the control, LN and foliar urea treatments relative to others, especially the HN-Apr+May+Jun+Jul. Reducing $\mathrm{N}$ fertilizer inputs could also help to minimize the environmental problems associated with sustained high levels of $\mathrm{N}$ fertilization in agroecosystems, but we could not quantify such externalities in this study (Weinbaum et al., 1992).

\section{Conclusion}

Nitrogen fertilization increased yields of 'GoldRush' mostly in the second year of our study, when leaf $\mathrm{N}$ concentrations were relatively low. High rates of $\mathrm{N}$ fertilizer partitioned into four applications from April to July increased yields relative to the same total amount of $\mathrm{N}$ in fewer applications. Relatively small amounts of urea-N applied in four foliar sprays during the growing season increased yields more than equivalent amounts of soil-applied $\mathrm{N}$ fertilizers. The two highest yielding treatments ( $\mathrm{HN}$ in April, May, June and July, and foliar urea in May, June, July and Aug), both involved $\mathrm{N}$ applications in the later stages of fruit development. Although identical fruit thinning sprays were applied to all $\mathrm{N}$ treatments, the total number of fruit set per tree was greater in $\mathrm{N}$ fertilizer treatments relative to unfertilized controls, and increased with split applications at high rates of $\mathrm{N}$ or foliar urea sprays. Average fruit weights were similar across all treatments in both years despite the greater aggregate yields from $\mathrm{N}$ fertilized trees. In other words, total yields of 'GoldRush' were increased by $\mathrm{N}$ fertilization, but fruit size did not increase proportionally with $\mathrm{N}$ fertilization amounts, because both fruit set and total crop load increased on $\mathrm{N}$ fertilized trees.

Cosmetic and internal fruit qualities such as yellow background color, red blush, firmness, and soluble solids were affected negatively by all $\mathrm{N}$ treatments relative to unfertilized trees. Estimated crop market values based on box-size categories were dependent on total yield and fruit-size distribution-both of which were affected by $\mathrm{N}$ treatments. Foliar urea applications produced the greatest net crop market value, followed by $\mathrm{HN}$ Apr+May+Jun+Jul, and LN-Apr+Jun 
treatments. Crop values for unfertilized trees were substantially lower than all $\mathrm{N}$ fertilizer treatments. Considering the costs of $\mathrm{N}$ fertilizer and labor for application, foliar urea and LNApr+Jun were probably the most economical $\mathrm{N}$ fertilization programs for this new apple variety, but fruit growers should thin 'GoldRush' aggressively to attain the potential benefits of $\mathrm{N}$ applications for increasing yields and fruit size.

\section{Literature cited}

Agnello, A.M., W.F. Wilcox, W.C. Stiles, J. Kovach, and P.D. Curtis. 1999. Pest management recommendations for commercial tree-fruit production. Cornell Univ. SAES, Geneva.

Beattie, J.M. 1958. Nitrogen fertilization of apples. Ohio Agr. Expt. Sta. Res. Bul. 817.

Blanpied, G.D. and K. Silsby. 1992. Predicting harvest date windows for apples. Cornell Univ. Coop. Ext. Bul. 221.

Crosby, J.A., J. Janick, P.C. Pecknold, J.C. Goffreda, and S. Korban. 1994. 'GoldRush' apple. HortScience 29(7):827-828.

Fallahi, E., W.S. Conway, K.D. Hickey, and C.E. Sams. 1997. The role of calcium and nitrogen in postharvest quality and disease resistance of apples. HortScience 32:831-834.

Fisher, E.G. and J.A. Cook. 1950. Nitrogen fertilization of the 'McIntosh' apple with leaf sprays of urea II. Proc. Amer. Soc. Hort. Sci. 55:35-40.

Goode, J.E., and K.H. Higgs. 1977. Effects of time of application of inorganic nitrogen fertilizers on apple trees in a grassed orchard. J. Hort. Sci. 52:317-334.

Greweling, T. 1976. Chemical analysis of plant tissue. Cornell Univ. Agr. Expt. Sta. Res. Bul. 6(8).

Greweling, T. and M. Peech. 1965. Chemical soil tests. Cornell Univ. Agr. Expt. Sta. Res. Bul. 960.

Hansen, P. 1980. Yield components and fruit development in 'Golden Delicious' apples as affected by the timing of nitrogen supply. Sci. Hort. 12:243-257.

Hipps, N.A., M.S. Ridout, and D. Atkinson. 1990. Effects of alley sward width, irrigation and nitrogen fertiliser on growth and yield of 'Cox's Orange Pippin' apple trees. J. Sci. Food. Agr. 53:159-168.

Johnson, D.S. and T.J. Samuelson. 1990. Short-term effects of changes in soil management and nitrogen fertilizer applica- tion on 'Bramley's Seedling' apple trees. I. Effects on tree growth, yield and leaf nutrient composition. J. Hort. Sci. 65:489493.

Khemira, H., A.N. Azarenko, D. Sugar, and T.L. Righetti. 1998. Postharvest nitrogen application effect on ovule longevity of 'Comice' pear trees. J. Plant Nutr. $21: 405-411$.

Magness, J.R., L.P. Batjer, and L.O. Regeimbal. 1948. Apple tree response to nitrogen applied at different seasons. J. Agr. Res. 76:1-25.

McGuire, R.G. 1992. Reporting of objective color measurements. HortScience 27:1254-1255.

Neilsen, G.H., E.J. Hogue, and M. Meheriuk. 1999. Nitrogen fertilization and orchard-floor vegetation management affect growth, nutrition, and fruit quality of 'Gala' apple. Can. J. Plant Sci. 79:379385 .

Neilsen, G.H., M. Meheriuk, and E.J. Hogue. 1984. The effect of orchard floor management and nitrogen fertilization on nutrient uptake and fruit quality of 'Golden Delicious' apple trees. HortScience 19:547-550.

Oland, K. 1960. Nitrogen feeding of apple trees by postharvest urea sprays. Nature. 185:857.

Overholser, E.L. and F.L. Overley. 1939. The effect of time of nitrogen application upon the response of 'Jonathan' apples. Proc. Amer. Soc. Hort. Sci. 37:81-84.

Raese, J.T. and S.R. Drake. 1997. Nitrogen fertilization and elemental composition affects fruit quality of 'Fuji' apples. J. Plant Nutr. 20:1797-1809.

Sanchez, E.E., T.L. Righetti, D. Sugar, and P.B. Lombard. 1992. Effects of timing of nitrogen application on nitrogen partitioning between vegetative, reproductive, and structural components of mature 'Comice' pears. J. Hort. Sci. 67:51-58.

Stiles, W.C. and W.S. Reid. 1991. Orchard nutrition management. Cornell Univ. Coop. Ext. Info. Bul. 219.

The Packer. 2000. Vance Publishing Co., Chicago, Ill. vol. 107. No. 1. 3 Jan. 2000.

Weinbaum, S.A., R.S. Johnson, and T.M. DeJong. 1992. Causes and consequences of over-fertilization in orchards. HortTechnology 2:112-121.

Williams, R.R. 1965. The effect of summer nitrogen applications on the quality of apple blossoms. J. Hort. Sci. 40:31-41.

Williams, R.R. and H.D. Billingsley. 1974. Effect of nitrogen fertilizer on yield, size and color of 'Golden Delicious' apple. J. Amer. Soc. Hort. Sci. 99:144-145. 